\title{
当院で施行された気管切開症例の合併症の検討
}

\author{
高松 一 郎*, 小河原 昇*, 大石 公 直** \\ 長 原 太 郎***, 佃 \\ 守***
}

\section{A Retrospective Study of Complications in Long-term Tracheostomized Children}

\author{
Ichirou Takamatsu, M.D., ${ }^{*}$ Noboru Ogahara, M.D., ${ }^{*}$ Kiminao Ooishi, M.D., ${ }^{* *}$ \\ Tarou Nagahara, M.D., ${ }^{* * *}$ and Mamoru Tsukuda, M.D.*** \\ *Department of Otorhinolaryngology, Kanagawa Children's Medical Center, Yokohama, \\ **Department of Otolaryngology, Yokohama City University, Urafune Hospital, \\ Yokohama, and ${ }^{* * *}$ Department of Otolaryngology, Yokohama City University, \\ School of Medicine, Yokohama
}

Tracheostomy was performed in 62 patients during a 23-year period (1970-1993) at our clinic. Complications were analysed in 41 cases with long-term tracheostoma over one year.

Twenty one cases with long-term tracheostoma suffered from complications. There were 9 cases with distal tracheal granulations, 7 with intrastomal granulomas, 7 with suprastomal granulomas and 3 with stomal infection and abcess. Other complications were pneumonia, pneumothorax, accidental extubation and so on.

Distal tracheal granulations are difficult to treat, and we preferred conservative therapies. First, we inserted a nasotracheal tube from the stoma to the lower site of the granulation. If scar formation was ocurred, we changed it to a conventional or flexible tracheal tube. If the granulation was too large to insert the nasotracheal tube, we excised the granulations with an YAG laser or electrocoagulator. Then we inserted a conventional or flexible tracheal tube. In some cases, we performed a laryngotracheal separation.

However, mild Hunter's disease appeared difficult to treat because of misdeglutition and tracheobronchomalacia. It is important to consider the disease, general conditions and selection of a tracheostomy tube for the management of pediatric cases with long-term tracheostoma.

Key words : tracheotomy, long-term, tracheal granuloma, flexible tracheotomy tube

\section{I . はじめに}

1970年当センター開設以来, 当科で気管切開

*神奈川県立こども医療センター耳鼻咽喉科, **横浜 市立大学浦舟病院耳鼻咽喉科, ${ }^{* * *}$ 横浜市立大学医学 部病院耳鼻咽喉科

別刷請求： $=254$ 神奈川県平塚市追分9-11

平塚共済病院耳鼻咽喉科 高松一郎

投稿受付：1994年10月12日
された症例は1993年 5 月現在 62 例に及ぶ。近年 は外科的治療の対象とならない内科的な疾患 で，気道確保の目的のため気管切開される症例 が徐々に増加してきており，48例を占めた。今 回は, 気管切開施行後気管切開孔が閉鎖されず 長期（ 1 年以上）を経過した 41 症例を対象とし, 合併症およびその治療法について検討したので 報告する。 
表 1 適応疾患

\begin{tabular}{|c|c|c|}
\hline \multicolumn{3}{|c|}{ 1) 先天性 } \\
\hline & 神経・筋疾患 & 13 例 \\
\hline & 声門下狭窄 & 4 例 \\
\hline & ピエールロバン症候群 & 2 例 \\
\hline & 代謝疾患 & 2 例 \\
\hline & 喉頭毫胞 & 2 例 \\
\hline & 両側反回神経麻㾇 & 1 例 \\
\hline & 中枢性低換気症候群 & 1 例 \\
\hline & Cardio-facial syndrome & 1 例 \\
\hline & Apert syndrome & 1 例 \\
\hline & Cerebrocostmandibular syndrome & 1 例 \\
\hline & 18 Trisomy & 1 例 \\
\hline & Rubinstein syndrome & 1 例 \\
\hline & 咽頭奇形腫 & 1 例 \\
\hline & 喉頭横隔膜症 & 1 例 \\
\hline \multicolumn{3}{|c|}{2 ) 後天性 } \\
\hline & 声門下狭窄 & 4 例 \\
\hline & 喉頭乳頭腫 & 1 例 \\
\hline & 肺線維症 & 1 例 \\
\hline & Guillain-Barre' syndrome & 1 例 \\
\hline & 声帯浮腫 & 1 例 \\
\hline & 脳腫場 & 1 例 \\
\hline
\end{tabular}

表 2 気管切開の方法

\begin{tabular}{clr}
\hline 皮 切 & 緹切開 & 28 例 \\
& 横切開 & 13 例 \\
甲状腺 & 上気管切開 & 1 例 \\
& 中気管切開 & 26 例 \\
& 下気管切開 & 14 例 \\
気管壁 & 逆U切開 & 25 例 \\
& 縦切開 & 8 例 \\
& H切開 & 5 例 \\
& 紡鍾切開 & 1 例 \\
& $\mathrm{U}$ 切開 & 2 例 \\
\hline
\end{tabular}

\section{II．対象および結果}

今回対象とした症例 41 例の内訳は, 神経・筋 疾患, 代謝疾患, 遺伝疾患などの内科的な疾患 が26例と多く(表 1), 咽頭, 喉頭, 気管などの 疾患で治療のために一時的な気管切開を要した 症例は15例で, 比較的長期におよぶ安全な気道 管理が主となる症例が多かった。
表 3 気管切開後の合併症（重複例あり）

\begin{tabular}{|c|c|}
\hline 気管肉芽 & 9 例 \\
\hline 気管切開孔上部の肉芽 & 7 例 \\
\hline 気管切開孔周囲の肉芽 & 7 例 \\
\hline 気管切開孔周囲の化膿・膿瘍 & 3 例 \\
\hline 急性肺炎 & 1 例 \\
\hline 気 胸 & 1 例 \\
\hline 気管カニューレの事故抜去 & 1 例 \\
\hline 気管切開孔閉鎖後の気管軟化 & 1 例 \\
\hline 気管切開孔の離開 & 1 例 \\
\hline 気管切開孔の気管軟骨の壊死 & 1 例 \\
\hline 気管内異物（Tチューブ） & 1 例 \\
\hline 気管切開孔周囲皮庯の壊死 & 1 例 \\
\hline
\end{tabular}

気管切開の方法は, 皮切は縦切開28例, 横切 開13例, 甲状腺の処理方法は上気管切開 1 例, 中気管切開26例, 下気管切開14例, 気管壁は逆 $\mathrm{U}$ 切開 25 例, 綐切開 8 例, $\mathrm{H}$ 切開 5 例, 紡鍾切 開 1 例, U切開 2 例であった（表 2 )。

気管切開後に合併症のみられた症例は41例中 21例と過半数にのほった（表 3 )。その内訳は, 気管切開孔下方の肉芽 9 例・気管切開孔上部の 肉芽 7 例・気管切開孔周囲の肉芽 7 例・気管切 開孔周囲の化膿, 膿瘍 3 例 - 急性肺炎, 気胸, 気管カニューレの事故抜去, 気管切開孔閉鎖後 の気管軟化, 気管切開孔の離開, 気管切開孔の 気管軟骨の壊死, 気管内異物 ( $\mathrm{T}$ チューブ), 気 管カニューレの圧迫による気管切開孔周囲皮膚 の壊死がそれぞれ 1 例ずつ見られた。

気管切開後 1 年以上経過した症例では気管の 肉芽性病変が合併症の主で，15例 $(71.4 \%)$ あ った。

手術直後の感染や縫合不全・気胸などの発生 頻度は少なく, 最も頻度の多かった気管切開孔 下方の肉芽は全症例とも気管カニューレの先端 部位で気管の前壁より発生しており，気管切開 より気管肉芽発生までの期間は最短で 3 力月, 最長で 2 年 1 力月であり, 全症例に誤嚥が見ら れた。気管切開孔上部や気管切開孔周囲の肉芽 は, 誤嚥のひどい症例ほど早く形成されやすく, 最も早い症例では術後 $1 \sim 2$ 力月より発生して いた。 


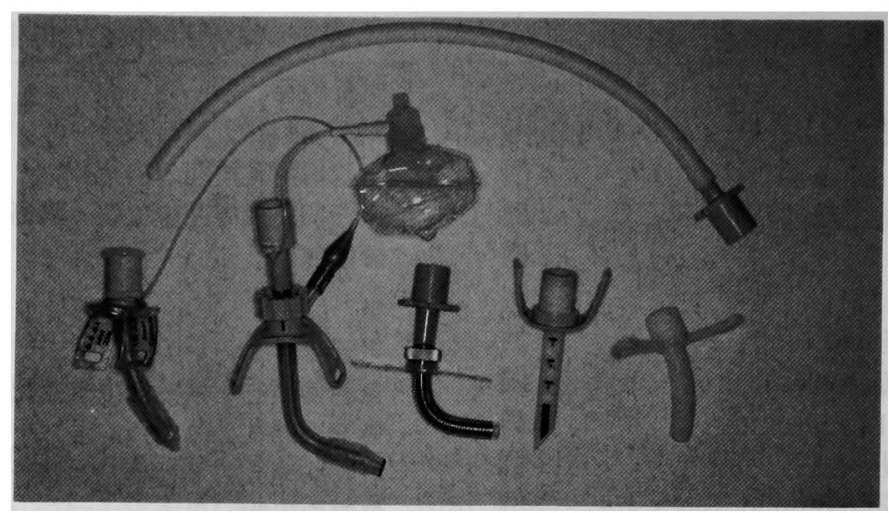

図 1 易撓性の気管切開チューブ

\section{III. 考察}

長期にわたって気道管理が必要なことから， 合併症 ${ }^{1 \sim 4}$ として生じやすく, 最も治療の障害 となる気管孔下方の肉芽に対しては, 肉芽の切 除のみではすぐに再発するため, 肉芽除去を行 わずに次のごとき処置を原則としている。

まず插管チューブを肉芽より深部に挿入し, しばらく様子をみる。その後, 肉芽や痏痕にな った症例に対しては再び気管カニューレに変更 する。この際, 気管カニューレの長さの変更, 挿管チューブで特殊なカニューレの作製, 長さ の調節ができる柔らかい材質の気管切開チュー ブに変更するなどの工夫をしている(図 1)。ま た気管切開チューブを深部に挿入する場合, 気 管分岐部に肉芽を作らないよう気管切開チュー ブの先端の位置が適当か, 吸引の時に気管分岐 部を刺激しないかなどに十分に注意する必要が ある。

しかしこれらの処置で対処できない場合や, 高度な狭窄が予想される場合は, ventilation bronchoscope 下にYAGレーザーなどを用い て肉芽の切除を施行している。

このように実際に用いてきた方法を表 4 にま とめてみた。単に柔らかい気管切開チューブに 変更するのみで気管孔下部の肉芽のコントロー ルがつき経過をみているものもあるが，気管切 開チューブの工夫のみでは誤曣や気管孔下部の 肉芽のコントロールが困難な場合には，最終的 には喉頭気管分離術を必要とせざるをえない症 例もあった
表 4 気管肉芽の治療の内容

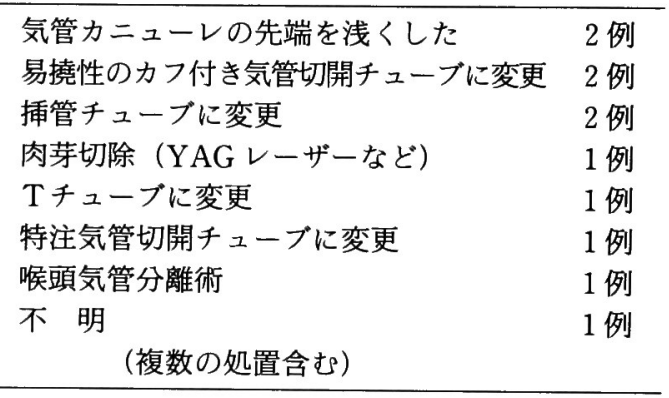

表 5 気管肉芽の形成された症例

\begin{tabular}{ll}
\hline Werdnig-Hoffman 病 & 2 例 \\
CP & 2 例 \\
Hunter 病 & 1 例 \\
声門下狭窄（後天性） & 1 例 \\
先天性筋ジトロフィー & 1 例 \\
脳腫瘍 & 1 例 \\
Cardio-facial syndrome & 1 例 \\
\hline
\end{tabular}

さらに再発した気管肉芽の症例は表 5 のよう になる。これらの疾患に共通する原因を検討し てみると, 誤與がひどく頻回に気管内吸引を要 する例や神経・筋疾患のため体動がほとんどみ られず気管切開チューブの先端が常に同じ位置 にあたったことなどが考えられる。

このような症例の対策として, まず気管内吸 引を減らすためには, 気管切開チューブのカフ を膨らますか, 喉頭気管分離術の施行が有効と 考える。最近の当院での方針としては，患者が 
小児であり気管孔下部の肉芽が再発している症 例にはあえてカフの長期的な使用は行わず，喉 頭気管分離術を行い，気管切開チューブを使用 しない方法をとっている。しかし全身状態や両 親の同意などの要因で, 前者の方法をとらざる をえない症例もある。

また気管切開チューブを使用しない方法だけ ならボタン状気管カニューレ8)を使用するとい う考え方もあるが，脱落事故や気管内吸引の問 題, 人工呼吸器使用時の問題を考えて, 現在の ところ当院での使用経験はない。

また気管切開チューブの長さを変更できるチ ューブがあり，この使用で先端の位置を定期的 にずらして肉芽のコントロールをしている症例 もある。しかしチューブの種類, 材質, サイズ, カフの有無などの点でまだ小児に対しての使用 にはかなり制約を受け，肉芽のコントロールに は最適なチューブの考案が望まれる。

さらに代謝疾患，たとえば軽症のハンタ一病 は比較的長期に生存する症例もあり，その末期 の気道管理に気管切開が必要になる。しかし気 管切開後も, 誤嚥や気管気管支軟化症の状態が 重なり，上記の手段を講じても気管肉芽のコン トロールが不良な疾患で安全な気道の確保に難 渋している9。

また気管切開孔上部, 周囲の肉芽から出血し たり, カニューレ交換が困難な症例では手術的 に肉芽を切除するだけでは不十分なことが多 い。長期に及ぶ気管切開症例の気管切開孔上 部・周囲の肉芽は切除しても気管粘膜の欠損が 残りすぐに再発することが多いので，手術的な 肉芽の切除は必要最小限にとどめるほうがよい と思われる ${ }^{10)}$ 。

\section{IV. まとめ}

1 年以上経過した気管切開症例は合併症とし て気管肉芽の発生率が高くなり, その治療に難
渋する。

長期にわたる安全で確実な気道の確保が求め られる症例の気管切開では, 術前に患者の原疾 患, 全身状態を十分に把握することが重要であ り, 単に気管切開のみでよいのか, 術後の気管 切開チューブの選択をも含めた総合的な検討が 必要なのか,この点を十分に把握することが重 要と思われた。

\section{文献}

1）石橋 康：小児の気管切開. 小児外科, vol. 14, no. 10, 75-79, 1982-10.

2 ) Chew, L.T.Y., and Cantrell, R.W. : Tracheostomy. Arch. Otolaryngol., 96:538-545, 1972.

3 ) Gaudet, T.P., Peerless, A., Sasaki, C.T., et al. : Pediatric tracheostomy and associated complications. Laryngoscope, $86: 331-340$, 1976.

4 ) Lawrence, W.C., Miller, L., Ralph, F., et al. : Endoscopic assessment in children with tracheotomies. Arch. Otolaryngol., 119:321324, 1993.

5 ) 堀口利之, 林田哲郎: 誤睘の手術的療法. JOHNS, 8:113-119, 1992.

6 ) 小河原昇：喉頭気管分離術.こども医療セン夕 一医学誌, 22:10-14, 1993.

7 ) Lindeman, R.C., Yarington, C.T., Jr., and Sutton, D. : Clinical experience with the tracheoesophageal anastomosis for intractable aspiration. Ann. Otol. Rhinol. Laryngol., 97 : 466-470, 1976.

8 ) 橋本紘治, 山地誠一, 寺山吉彦: 気管孔用力フ スボタン状カニューレの考案. 日気食会報, 31 : 269-276, 1980

9 ) Sasaki, C.T., Ruiz, R., Gaito, R., Jr., et al. : Hunter' syndrome: A study in airway obstruction. Laryngoscope, $97: 280-285$, 1987.

10) Rosenfeld, R.M., and Stool, E.S. : Should granulomas be excised in children with long. term tracheotomy? Arch. Otolaryngol., $118: 1323-1327,1992$. 